\title{
Altererythrobacter namhicola sp. nov. and Altererythrobacter aestuarii sp. nov., isolated from seawater
}

\author{
Seong Chan Park, ${ }^{1}$ Keun Sik Baik, ${ }^{1}$ Han Na Choe, ${ }^{1}$ Chae Hong Lim, ${ }^{1}$ \\ Ho Jun Kim, ${ }^{1}$ Jong-Ok Ka ${ }^{2}$ and Chi Nam Seong ${ }^{1}$ \\ ${ }^{1}$ Department of Biological Science, College of Life Science and Natural Resources, Sunchon \\ National University, Suncheon 540-742, Republic of Korea \\ ${ }^{2}$ Department of Agricultural Biotechnology, Seoul National University, Seoul 151-921, Republic of \\ Korea
}

Correspondence

Chi Nam Seong

scnu@scnu.ac.kr

Two non-motile, orange- or yellow-pigmented bacteria, designated strains $\mathrm{KYW}^{\top}{ }^{\top}$ and KYW $147^{\top}$, were isolated from seawater collected from the South Sea, Republic of Korea. Cells of both strains were Gram-reaction-negative, aerobic and catalase- and oxidase-positive. The major fatty acids of strain $\mathrm{KYW} 48^{\top}$ were $\mathrm{C}_{18: 1} \omega 7 \mathrm{c}(35.3 \%)$, summed feature 3 (iso- $\mathrm{C}_{15: 0} 2-\mathrm{OH}$ and/ or $\left.\mathrm{C}_{16: 1} \omega 7 c\right)(22.7 \%), \mathrm{C}_{17: 1} \omega 6 c(19.8 \%), \mathrm{C}_{14: 0} 2-\mathrm{OH}(7.4 \%)$ and $\mathrm{C}_{16: 0}(5.9 \%)$, and those of strain $\mathrm{KYW} 147^{\top}$ were $\mathrm{C}_{18: 1} \omega 7 c(36.0 \%)$, summed feature $3(18.3 \%), \mathrm{C}_{16: 0}(14.7 \%)$, 11-methyl $\mathrm{C}_{18: 1} \omega 7 c(10.7 \%), \mathrm{C}_{16: 0} 2-\mathrm{OH}(9.1 \%)$ and $\mathrm{C}_{18: 1} \omega 9 c$ (8.0\%). The predominant isoprenoid quinone of both strains was ubiquinone $10(\mathrm{Q}-10)$. The DNA G $+\mathrm{C}$ contents of strains KYW48 ${ }^{\top}$ and $\mathrm{KYW} 147^{\top}$ were 63.8 and $67.2 \mathrm{~mol} \%$, respectively. A phylogenetic tree based on $16 \mathrm{~S}$ rRNA gene sequences showed that strains $\mathrm{KYW} 48^{\top}$ and $\mathrm{KYW} 147^{\top}$ were grouped with the members of the family Erythrobacteraceae and formed a distinct clade with the members of the genus Altererythrobacter ( $<95.7 \%$ sequence similarity). On the basis of the evidence presented in this study, the novel species Altererythrobacter namhicola sp. nov. (type strain $\mathrm{KYW}^{\mathrm{N}} \mathrm{8}^{\mathrm{T}}$ $=\mathrm{KCTC} 22736^{\top}=\mathrm{JCM} 16345^{\top}$ ) and Altererythrobacter aestuarii sp. nov. (type strain KYW147 $=\mathrm{KCTC} 22735^{\top}=\mathrm{JCM} 16339^{\top}$ ) are proposed.

The genus Altererythrobacter was proposed by Kwon et al. (2007) and belongs to the family Erythrobacteraceae (Lee et al., 2005). At the time of writing, the genus included five species, Altererythrobacter epoxidivorans (type species; Kwon et al., 2007), A. luteolus (Yoon et al., 2005; Kwon et al., 2007), A. indicus (Ramesh Kumar et al., 2008), A. marinus (Lai et al., 2009) and A. marensis (Seo \& Lee, 2010). Members of the genus have been isolated from marine environments such as the mangrove rhizosphere, cold-seep sediments and seawater of tidal flats. Altererythrobacter species are Gram-reactionnegative, aerobic, chemo-organotrophic, non-motile, yellowpigmented and lacking in bacteriochlorophyll (BChl) $a$ (Kwon et al., 2007). In the course of our study on the

\footnotetext{
Abbreviations: BChl, bacteriochlorophyll; DPG, diphosphatidylglycerol; GL, unknown glycolipid; PC, phosphatidylcholine; PE, phosphatidylethanolamine; PG, phosphatidylglycerol; PL, unknown phospholipid; SGL, sphingoglycolipid.

The GenBank/EMBL/DDBJ accession numbers for the 16S rRNA gene sequence of strains $\mathrm{KYW}^{\mathrm{T}}{ }^{\top}$ and $\mathrm{KYW}^{147^{\top}}$ are FJ935793 and FJ997597, respectively.
}

Two supplementary figures and a supplementary table are available with the online version of this paper. microbial diversity of seawater, two bacterial strains, designated $\mathrm{KYW} 48^{\mathrm{T}}$ and $\mathrm{KYW} 147^{\mathrm{T}}$, were isolated and were the subject of a taxonomic investigation.

Gwangyang Bay $\left(34^{\circ} 51^{\prime} \mathrm{N} 127^{\circ} 47^{\prime} \mathrm{E}\right)$ is located on the southern coast of Korea. Strains KYW $48^{\mathrm{T}}$ and $\mathrm{KYW} 147^{\mathrm{T}}$ were isolated from seawater samples collected from Gwangyang Bay in July 2008, using the standard dilution plating technique. Seawater samples were collected from a shallow coastal region $\left(2 \mathrm{~m}\right.$ depth; $\mathrm{KYW} 147^{\mathrm{T}}$ ) and from the mouth (30 $\mathrm{m}$ depth; KYW $48^{\mathrm{T}}$ ) of the bay in the morning at high tide. The physico-chemical properties of the seawater samples were as follows: at $2 \mathrm{~m}$ depth, $\mathrm{pH} \mathrm{8.2,} \mathrm{temperature} 28.0^{\circ} \mathrm{C}$, salinity $26.4 \%$; at $30 \mathrm{~m}, \mathrm{pH} 8.2$, temperature $26.2{ }^{\circ} \mathrm{C}$, salinity $29.0 \%$. Isolation was achieved on marine agar 2216 (MA; Becton Dickinson) (Yang et al., 2006) at $25{ }^{\circ} \mathrm{C}$ for 7 days. The isolates were routinely cultured on $\mathrm{MA}$ and maintained at $-80{ }^{\circ} \mathrm{C}$ as suspensions in marine broth (MB; Becton Dickinson) containing glycerol (20\%, w/v). Reference strains A. epoxidivorans JCM $13815^{\mathrm{T}}, A$. indicus KACC $13863^{\mathrm{T}}$ and $A$. luteolus KCTC $12311^{\mathrm{T}}$ were obtained from culture collections. A. marensis $\mathrm{MSW}-14^{\mathrm{T}}$ and A. marinus $\mathrm{H} 32^{\mathrm{T}}$ were gifts from Professor S. D. Lee (Jeju University, Korea) and Director Z. Shao (State Oceanic Administration, China). 
Bacterial DNA preparation and PCR amplification and sequencing of the $16 \mathrm{~S}$ rRNA gene were carried out as described previously (Chun \& Goodfellow, 1995). Identification of phylogenetic neighbours and calculation of pairwise 16S rRNA gene sequence similarities were achieved using the EzTaxon server (http://www.eztaxon. org/; Chun et al., 2007). Related sequences and the novel sequences were aligned by using CLUSTAL_X (Thompson et al., 1997) and the alignment was refined using PHYDIT version 3.1 (http://plaza.snu.ac.kr/ jchun/phydit/). Phylogenetic analysis was performed by using the computer packages PHYLIP (Felsenstein, 1993) and PAUP* 4.0 (Swofford, 1998). Phylogenetic trees were inferred using the maximum-likelihood (Felsenstein, 1993), maximum-parsimony (Fitch, 1971) and neighbour-joining (Saitou \& Nei, 1987) algorithms. The distance matrix for the neighbourjoining method was generated according to the model of Jukes \& Cantor (1969). The robustness of the topology of the phylogenetic trees was evaluated by bootstrap analyses (Felsenstein, 1985) of the neighbour-joining method based on 1000 resamplings.

Preliminary sequence comparison with 165 rRNA gene sequences held in GenBank indicated that the two isolates were related to the family Erythrobacteraceae. Strains $\mathrm{KYW} 48^{\mathrm{T}}$ and $\mathrm{KYW} 147^{\mathrm{T}}$ showed the highest $16 \mathrm{~S}$ rRNA gene sequence similarity to each other $(96.2 \%)$ followed by type strains of other Altererythrobacter species $(<95.9 \%)$. To elucidate the phylogenetic relationship between the novel isolates and other species of the family Erythrobacteraceae, phylogenetic trees were constructed using three different tree-making algorithms. The neighbourjoining tree (Fig. 1) showed that strains $\mathrm{KYW} 48^{\mathrm{T}}$ and $\mathrm{KYW} 147^{\mathrm{T}}$ were grouped with the members of the genus
Altererythrobacter and formed a distinct phyletic line distinguishable from other Altererythrobacter species, as in the maximum-parsimony and maximum-likelihood trees.

Physiological tests were carried out on strains KYW $48^{\mathrm{T}}$ and $\mathrm{KYW} 147^{\mathrm{T}}$ and the reference strains under the same conditions. Cells grown on MA for 2 days or to exponential phase in $\mathrm{MB}$ at $30{ }^{\circ} \mathrm{C}$ were used as the inoculum for physiological tests. Growth on various standard bacteriological media, nutrient agar (NA; Becton Dickinson), tryptic soy agar (TSA; Becton Dickinson), R2A agar (Becton Dickinson) and glucoseyeast extract agar (GYEA; Gordon \& Mihm, 1962), was tested according to the manufacturer's instructions. The morphology of cells grown at $30{ }^{\circ} \mathrm{C}$ for 2 days in $\mathrm{MB}$ was observed with a phase-contrast microscope (TMS-F; Nikon) and a scanning electron microscope (S-4800; Hitachi). For scanning electron microscopy, a subsample was soaked for several hours in $0.1 \mathrm{M}$ sodium phosphate buffer ( $\mathrm{pH} 7.4$ ), fixed in $0.5 \%$ glutaraldehyde and $0.5 \%$ paraformaldehyde in $0.1 \mathrm{M}$ sodium phosphate buffer ( $\mathrm{pH}$ 7.4) and dehydrated through an ethanol/isoamyl alcohol series. The sample was subsequently criticalpoint-dried in an SPI dry (JSM 5310; SPI Supplies) apparatus and osmium coater (Hollow Cathode Plasma CVD; Vacuum Device). Gliding motility was investigated by examining the edge of a hanging drop of a fresh $\mathrm{MB}$ culture, as recommended by Bernardet et al. (2002). The requirement for $\mathrm{NaCl}$ (final concentration $0-12 \%$, in increments of $1 \%$ ) for growth was tested using synthetic ZoBell liquid and agar medium (ZoBell, 1941; 5 g Bacto peptone, $1 \mathrm{~g}$ yeast extract, $0.1 \mathrm{~g}$ ferric citrate and $15 \mathrm{~g}$ Bacto agar in 11 distilled water) for up to 7 days. All media used in physiological tests were supplemented with $2 \%$

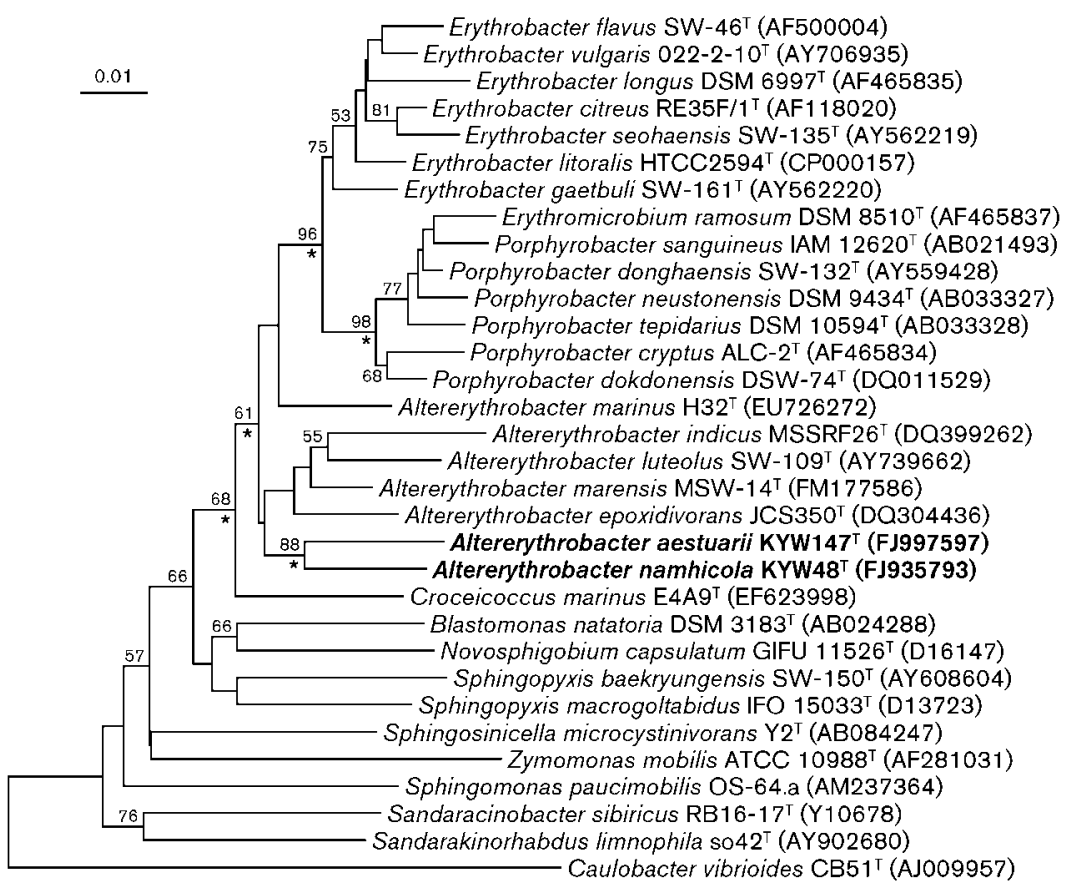

Fig. 1. Neighbour-joining tree based on $16 \mathrm{~S}$ rRNA gene sequences showing the phylogenetic position of strains $\mathrm{KYW}^{\mathrm{T}} 8^{\top}$ and $\mathrm{KYW} 147^{\top}$ within the family Erythrobacteraceae. Evolutionary distances, generated using the JukesCantor model, were based on 1319 unambiguously aligned nucleotides. Bootstrap support percentages $(>50 \%)$ are shown at nodes. Asterisks indicate that the corresponding branch was found in both the maximumparsimony and maximum-likelihood trees. Bar, 0.01 substitutions per nucleotide position. 
$\mathrm{NaCl}$ unless MA or $\mathrm{MB}$ was used. The $\mathrm{pH}$ range for growth was determined in ZoBell's liquid medium supplemented with $2 \%(\mathrm{w} / \mathrm{v}) \mathrm{NaCl}$; the medium was adjusted to $\mathrm{pH} 4-11$ (in increments of $1 \mathrm{pH}$ unit) by the addition of $\mathrm{HCl}$ and $\mathrm{NaOH}$ and sterilized by filtration. Growth temperature (4$\left.50{ }^{\circ} \mathrm{C}\right)$ and growth in an anaerobic chamber $\left(\mathrm{CO}_{2} / \mathrm{H}_{2} / \mathrm{N}_{2}\right.$, $10: 10: 80$; Sheldon Manufacturing) were examined on MA after incubation for up to 1 week. Catalase and oxidase activities were determined using $3 \%(\mathrm{v} / \mathrm{v})$ hydrogen peroxide and Kovács' reagent (Kovács, 1956), respectively. Acid production from glucose was tested as described by Yamaguchi \& Yokoe (2000). Nitrate reduction was tested in $\mathrm{MB}$ containing $0.2 \% \mathrm{KNO}_{3}$ (Skerman, 1967). Indole production was determined with Kovács' indole reagent on SIM agar (Becton Dickinson). $\mathrm{H}_{2} \mathrm{~S}$ production was determined on Kligler iron agar (Becton Dickinson). Hydrolysis of CM-cellulose $(1 \%, \mathrm{w} / \mathrm{v})$, casein $(2 \%, \mathrm{w} / \mathrm{v}$, skimmed milk), egg yolk ( $10 \%$, w/v), starch $(0.2 \%$, w/v) and Tweens 20 and 80 (both $1 \%$, w/v) was tested as described by Smibert \& Krieg (1994) using MA as the basal medium. Hydrolysis of L-tyrosine $(0.5 \%, \mathrm{w} / \mathrm{v})$ and xylan $(1 \%, w / v)$ were tested using MA as the basal medium (Barrow \& Feltham, 1993). DNase activity was determined with DNase test agar (Becton Dickinson) supplemented with $2 \%(\mathrm{w} / \mathrm{v}) \mathrm{NaCl}$. Other biochemical characters and enzyme activities were tested using the API 20NE and API ZYM kits (bioMérieux) and the GN2 MicroPlate (Biolog), prepared according to the manufacturers' instructions except that bacterial strains were suspended in distilled water supplemented with $2 \%(\mathrm{w} / \mathrm{v}) \mathrm{NaCl}$. Antibiotic resistance was determined by the disc diffusion method using commercial antibiotic-impregnated discs (BBL Becton Dickinson). After 5 days of incubation at $25{ }^{\circ} \mathrm{C}$ on MA, the results were interpreted according to the guidelines set forth by the CLSI (2003). Cellular pigments were extracted with methanol from a culture grown on MA and absorption spectra were measured with a spectrophotometer (UV-2100Pro; Amersham).

The two isolates formed circular, convex, smooth and opaque colonies with entire margins, approximately 1.0 $2.0 \mathrm{~mm}$ in diameter after 7 days at $30{ }^{\circ} \mathrm{C}(\mathrm{pH} 7)$. They produced orange $\left(\mathrm{KYW} 48^{\mathrm{T}}\right)$ or yellow $\left(\mathrm{KYW} 147^{\mathrm{T}}\right)$ pigments. Physiological, morphological and biochemical characteristics are described in Table 1 and in the species descriptions. The absence of pleomorphism, motility and $\mathrm{BChl} a$ in strains KYW $48^{\mathrm{T}}$ and KYW $147^{\mathrm{T}}$ indicated that the two strains could not be affiliated to the genus Erythromicrobium or Porphyrobacter (Yoon et al., 2006; Yurkov et al., 1994). No shared intrageneric characters were found that discriminate the genus Altererythrobacter, including strains $\mathrm{KYW} 48^{\mathrm{T}}$ and $\mathrm{KYW} 147^{\mathrm{T}}$, from the genus Erythrobacter. However, a number of phenotypic characteristics clearly distinguished strains KYW $48^{\mathrm{T}}$ and $\mathrm{KYW} 147^{\mathrm{T}}$ from other species in the genus Altererythrobacter (Ivanova et al., 2005; Kwon et al., 2007; Yoon et al., 2005).

Cells of the isolates and reference strains grown on MA for 2 days at $28{ }^{\circ} \mathrm{C}$ were prepared in duplicate and analysed for fatty acids by GLC according to the instructions of the Microbial Identification System (MIDI, 1999). Polar lipids were isolated by using standard procedures (Komagata \& Suzuki, 1987) and separated by TLC according to the method of Minnikin et al. (1975). Isoprenoid quinones were isolated by using the method of Minnikin et al. (1984) and were analysed by HPLC (Varian) as described by Collins (1985). For G $+C$ content calculations, the DNA sample was prepared in triplicate and the $\mathrm{G}+\mathrm{C}$ content was determined by the thermal denaturation method (Marmur \& Doty, 1962).

The fatty acid profiles of strains KYW $48^{\mathrm{T}}$ and KYW $147^{\mathrm{T}}$ are given in Table 2 . The predominant fatty acid of strains KYW $48^{\mathrm{T}}$ and $\mathrm{KYW} 147^{\mathrm{T}}$ was the monounsaturated fatty acid $\mathrm{C}_{18: 1} \omega 7 c$, as in Altererythrobacter species. However, significant differences were found between the strains in the composition and content of major fatty acids. The DNA G + C contents of strains $\mathrm{KYW} 48^{\mathrm{T}}$ and $\mathrm{KYW} 147^{\mathrm{T}}$ were 63.8 and $67.2 \mathrm{~mol} \%$, respectively. Both strains had ubiquinone $10(\mathrm{Q}-10)$ as a predominant isoprenoid quinone, as for all members of the family Erythrobacteraceae (Ramesh Kumar et al., 2008; Kwon et al., 2007).

The polar lipid profile of strain $\mathrm{KYW} 48^{\mathrm{T}}$ consisted of the major compounds diphosphatidylglycerol (DPG), phosphatidylethanolamine (PE), sphingoglycolipid (SGL) and unknown phospholipid (PL3) and minor amounts of phosphatidylcholine (PC), phosphatidylglycerol (PG), an unknown glycolipid (GL2) and an unknown phospholipid (PL1) (Supplementary Fig. S1, available in IJSEM Online), whereas that of strain KYW $147^{\mathrm{T}}$ consisted of the major compounds DPG, PE, PG, SGL and PC and minor amounts of unknown glycolipid GL1 and unknown phospholipids PL1 and PL2 (Supplementary Fig. S1). A. epoxidivorans and $A$. indicus contained an unknown aminolipid as a minor polar lipid (Ramesh Kumar et al., 2008). The absence of this unknown aminolipid in strains $\mathrm{KYW} 147^{\mathrm{T}}$ and $\mathrm{KYW} 48^{\mathrm{T}}$ is a striking characteristic that may be useful for differentiation at the species level.

On the basis of the data from this polyphasic study, strains KYW $48^{\mathrm{T}}$ and $\mathrm{KYW} 147^{\mathrm{T}}$ represent novel species of the genus Altererythrobacter, for which the names Altererythrobacter namhicola sp. nov. and Altererythrobacter aestuarii sp. nov., respectively, are proposed.

\section{Description of Altererythrobacter namhicola sp. nov.}

Altererythrobacter namhicola (nam.hi'co.la. N.L. n. namhae Namhae, the Korean name of the South Sea; L. suff. -cola from L. n. incola a dweller, inhabitant; N.L. masc. n. namhicola a dweller of the South Sea, referring to the isolation of the type strain).

Cells are non-motile, ovoid rods, $1 \mu \mathrm{m}$ wide and $1.4 \mu \mathrm{m}$ long (Supplementary Fig. S2a). Colonies on MA are orange-pigmented, circular, smooth and convex with 
Table 1. Characteristics that differentiate strains $\mathrm{KYW} 8^{\top}$ and $\mathrm{KYW} 147^{\top}$ from type strains of Altererythrobacter species

Strains: 1, KYW48 ${ }^{\mathrm{T}}$; 2, KYW147 ${ }^{\mathrm{T}}$; 3, A. epoxidivorans JCM $13815^{\mathrm{T}} ; 4$, A. indicus KACC $13863^{\mathrm{T}}$; 5, A. marensis MSW-14 ${ }^{\mathrm{T}}$; 6, A. marinus H32 ${ }^{\mathrm{T}}$; 7 , A. luteolus $\mathrm{KCTC} 12311^{\mathrm{T}}$. Data are from this study unless indicated. All strains are rod-shaped, show optimum growth at $30{ }^{\circ} \mathrm{C}$ and are positive for hydrolysis of aesculin and Tweens 20 and 80 and activity of catalase, alkaline phosphatase and leucine arylamidase. All strains are negative for nitrate reduction, presence of $\mathrm{BChl} a$, production of $\mathrm{H}_{2} \mathrm{~S}$ and indole, assimilation of $\mathrm{N}$-acetylglucosamine, adipate, arabinose, caprate, citrate, gluconate, glucose, mannitol, mannose and phenylacetate, hydrolysis of casein, CM-cellulose, egg yolk and xylan and activity of $N$-acetyl- $\beta$ glucosaminidase, arginine dihydrolase, $\beta$-glucuronidase, lipase (C14) and $\alpha$-mannosidase.

\begin{tabular}{|c|c|c|c|c|c|c|c|}
\hline Characteristic & 1 & 2 & 3 & 4 & 5 & 6 & 7 \\
\hline Colony colour & Orange & Yellow & Yellow & Yellow & Yellow & Yellow & Yellow \\
\hline Oxidase & + & + & + & - & + & + & + \\
\hline \multicolumn{8}{|l|}{$\mathrm{NaCl}$ concentration for growth $(\% \mathrm{w} / \mathrm{v})$} \\
\hline Range & $1-2$ & $0-6$ & $0-6$ & $0-13$ & $0-8$ & $0-8$ & $1-6$ \\
\hline Optimum & 1 & 1 & 2 & 2 & 2 & 2 & 2 \\
\hline Temperature range for growth $\left({ }^{\circ} \mathrm{C}\right)$ & $15-37$ & $10-40$ & $10-42$ & $4-42$ & $10-42$ & $10-42$ & $10-42$ \\
\hline \multicolumn{8}{|l|}{ Hydrolysis of: } \\
\hline DNA & - & - & - & + & - & - & - \\
\hline Gelatin & - & - & + & - & - & - & + \\
\hline Starch & + & - & - & + & - & - & - \\
\hline Tyrosine & + & - & + & + & - & - & - \\
\hline Urea & - & - & + & - & - & - & - \\
\hline \multicolumn{8}{|l|}{ Assimilation of: } \\
\hline Malate & - & - & - & - & - & + & - \\
\hline Maltose & - & - & - & - & + & - & - \\
\hline \multicolumn{8}{|l|}{ Enzyme activity (API ZYM) } \\
\hline Acid phosphatase & + & - & + & + & + & + & + \\
\hline$\alpha$-Chymotrypsin & + & - & + & - & + & + & + \\
\hline Cystine arylamidase & - & - & + & - & - & - & - \\
\hline Esterase (C4) & - & - & + & + & - & + & + \\
\hline Esterase lipase (C8) & - & - & + & - & + & + & + \\
\hline$\alpha$-Galactosidase & - & - & - & + & - & - & + \\
\hline$\beta$-Galactosidase & - & - & - & + & - & - & + \\
\hline$\alpha$-Glucosidase & - & - & - & - & + & - & + \\
\hline$\beta$-Glucosidase & - & + & - & + & - & - & - \\
\hline Naphthol-AS-BI-phosphohydrolase & + & - & + & + & - & + & + \\
\hline Trypsin & + & + & + & - & + & + & + \\
\hline Valine arylamidase & + & - & + & + & + & + & - \\
\hline DNA G $+C$ content $(\mathrm{mol} \%)$ & 63.8 & 67.2 & $54.5^{a}$ & $66.8^{b}$ & $63.1^{c}$ & $66.5^{d}$ & $60.3^{e}$ \\
\hline
\end{tabular}

${ }^{\star}$ Data from: a, Kwon et al. (2007); b, Ramesh Kumar et al. (2008); c, Seo \& Lee (2010); d, Lai et al. (2009); e, Yoon et al. (2005).

entire margins, approximately $1.0-2.0 \mathrm{~mm}$ in diameter after 7 days at $30{ }^{\circ} \mathrm{C}(\mathrm{pH} 7)$. Growth occurs at $15-37{ }^{\circ} \mathrm{C}$ (optimum, $30{ }^{\circ} \mathrm{C}$ ) and at $\mathrm{pH}$ 5-11 (optimum, $\mathrm{pH} \mathrm{6-7).}$ Growth occurs in $1-2 \%(\mathrm{w} / \mathrm{v}) \mathrm{NaCl}$. Does not contain BChl $a$ as a photosynthetic pigment. Methanol-soluble pigment is characterized by an absorption maximum at $460 \mathrm{~nm}$. Oxidase- and catalase-positive. Negative for acid production from D-glucose and maltose, production of indole and $\mathrm{H}_{2} \mathrm{~S}$, nitrate reduction and assimilation of $\mathrm{N}$ acetylglucosamine, adipate, arabinose, caprate, citrate, gluconate, glucose, malate, maltose, mannitol, mannose and phenylacetate. Aesculin, starch, L-tyrosine and Tweens 20 and 80 are degraded, but casein, CM-cellulose, DNA, egg yolk, gelatin, urea and xylan are not. In the API ZYM gallery, acid and alkaline phosphatase, $\alpha$-chymotrypsin, leucine arylamidase, naphthol-AS-BI-phosphohydrolase, trypsin and valine arylamidase activities are present, but $N$-acetyl- $\beta$-glucosaminidase, esterase (C4), esterase lipase (C8), cystine arylamidase, $\alpha$-fucosidase, $\alpha$ - and $\beta$-galactosidase, $\alpha$ - and $\beta$-glucosidase, $\beta$-glucuronidase, lipase (C14) and $\alpha$-mannosidase activities are absent. In the GN2 microplate (Biolog), acetic acid, $\gamma$-aminobutyric acid, DLcarnitine, $\alpha$-cyclodextrin, dextrin, glycyl L-aspartic acid, glucose 1-phosphate, glucose 6-phosphate, DL- $\alpha$-glycerol phosphate, glycyl L-glutamic acid, $\beta$-hydroxybutyric acid, succinic acid, succinamic acid, L-phenylalanine, L-alanine (weak), L-alaninamide (weak), L-alanyl glycine (weak), $\alpha$ ketoglutaric acid (weak), phenylethylamine (weak), Lproline (weak), L-pyroglutamic acid (weak) and D-serine (weak) are utilized. The remaining substrates of the Biolog GN2 system are not utilized (Supplementary Table S1). Cells are sensitive to ( $\mu \mathrm{g}$ per disc, unless indicated) 
Table 2. Cellular fatty acid contents of strains $\mathrm{KYW}_{4} 8^{\top}$ and $\mathrm{KYW} 147^{\top}$ and type strains of Altererythrobacter species

Strains: 1, KYW48 ${ }^{\mathrm{T}} ; 2, \mathrm{KYW}_{147^{\mathrm{T}}}$; 3, A. epoxidivorans JCM $13815^{\mathrm{T}} ;$ 4, A. indicus KACC $13863^{\mathrm{T}} ; 5$, A. marensis MSW-14 ${ }^{\mathrm{T}}$; 6, A. marinus H32 ${ }^{\mathrm{T}}$; 7, A. luteolus KCTC $12311^{\mathrm{T}}$. Data were obtained in this study using cells grown on MA for 3 days at $30{ }^{\circ} \mathrm{C}$. Values are percentages of total fatty acids; - , not present.

\begin{tabular}{|c|c|c|c|c|c|c|c|}
\hline Fatty acid & 1 & 2 & 3 & 4 & 5 & 6 & 7 \\
\hline \multicolumn{8}{|l|}{ Straight-chain } \\
\hline $\mathrm{C}_{15: 0}$ & 3.2 & - & - & - & 0.8 & - & - \\
\hline $\mathrm{C}_{18: 0}$ & - & - & - & 0.5 & - & - & - \\
\hline \multicolumn{8}{|l|}{ Unsaturated } \\
\hline $\mathrm{C}_{16: 1} \omega 5 c$ & - & - & 3.2 & - & 1.9 & 1.1 & 3.1 \\
\hline $\mathrm{C}_{17: 1} \omega 8 c$ & 2.1 & - & - & 1.2 & - & 0.7 & - \\
\hline $\mathrm{C}_{18: 1} \omega 5 c$ & - & - & 1.2 & 1.0 & - & 1.9 & 1.1 \\
\hline $\mathrm{C}_{18: 1} \omega 7 c$ & 35.2 & 36.1 & 42.6 & 63.6 & 40.4 & 48.8 & 41.7 \\
\hline $\mathrm{C}_{18: 1} \omega 9 \mathrm{c}$ & - & 7.9 & - & - & - & - & - \\
\hline 11-Methyl $C_{18: 1} \omega 7 c$ & - & 11.0 & 6.0 & - & 18.1 & 23.7 & 5.0 \\
\hline \multicolumn{8}{|l|}{ Cyclopropane acids } \\
\hline \multicolumn{8}{|l|}{ Hydroxy } \\
\hline $\mathrm{C}_{16: 0} 2-\mathrm{OH}$ & - & 9.0 & 2.1 & 0.8 & 3.0 & 1.8 & 2.1 \\
\hline $\mathrm{C}_{17: 0} 3-\mathrm{OH}$ & - & - & 3.2 & 4.5 & 5.4 & 2.7 & 5.3 \\
\hline $\mathrm{C}_{16: 1} 2-\mathrm{OH}$ & - & - & 1.2 & - & - & - & 1.2 \\
\hline Summed feature $3^{*}$ & 22.7 & 18.4 & 29.8 & 1.1 & 12.7 & 4.6 & 29.1 \\
\hline
\end{tabular}

${ }^{\star}$ Summed features are groups of two or three fatty acids that cannot be separated by GLC with the Microbial Identification System. Summed feature 3 consists of $\mathrm{C}_{16: 1} \omega 7 c$ and/or iso- $\mathrm{C}_{15: 0} 2-\mathrm{OH}$.

ampicillin (10), chloramphenicol (30), erythromycin (15), penicillin (10 IU), tetracycline (30) and vancomycin (30), but resistant to amikacin (30), gentamicin (10), kanamycin (30), nalidixic acid (30), polymyxin B (300 IU) and streptomycin (10). DPG, PE, SGL and unknown phospholipid PL3 are the major polar lipids (Supplementary Fig. S1). The predominant whole-cell fatty acids $(>5 \%)$ are $\mathrm{C}_{18: 1} \omega 7 c$, summed feature 3 (iso- $\mathrm{C}_{15: 0} 2-\mathrm{OH}$ and/or $\left.\mathrm{C}_{16: 1} \omega 7 c\right), \mathrm{C}_{17: 1} \omega 6 c, \mathrm{C}_{14: 0} 2-\mathrm{OH}$ and $\mathrm{C}_{16: 0}$. The predominant isoprenoid quinone is $\mathrm{Q}-10$. The DNA $\mathrm{G}+\mathrm{C}$ content of the type strain is $63.8 \mathrm{~mol} \%$.

The type strain, KYW48 ${ }^{\mathrm{T}}\left(=\mathrm{KCTC} 22736^{\mathrm{T}}=\mathrm{JCM} 16345^{\mathrm{T}}\right)$, was isolated from a seawater sample collected from the South Sea, Republic of Korea.

\section{Description of Altererythrobacter aestuarii sp. nov.}

Altererythrobacter aestuarii (aes.tu.a'ri.i. L. gen. n. aestuarii of a tidal flat, from where the type strain was isolated).

Cells are non-motile rods, $1 \mu \mathrm{m}$ wide and 3.5-5.7 $\mu \mathrm{m}$ long (Supplementary Fig. S2b). Colonies on MA are yellowpigmented, circular, smooth and convex with entire margins, approximately $1.0-2.0 \mathrm{~mm}$ in diameter after 7 days at $30{ }^{\circ} \mathrm{C}(\mathrm{pH} 7)$. Growth occurs at $10-40{ }^{\circ} \mathrm{C}$ (optimum, $30{ }^{\circ} \mathrm{C}$ ) and at $\mathrm{pH} 5-11$ (optimum, $\mathrm{pH} 6-8$ ). Growth occurs in $0-6 \%(\mathrm{w} / \mathrm{v}) \mathrm{NaCl}$ (optimum 1-2\%). Does not contain $\mathrm{BChl} a$ as a photosynthetic pigment. Methanol-soluble pigment is characterized by absorption maxima at 447 and $475 \mathrm{~nm}$. Oxidase- and catalasepositive. Negative for acid production from D-glucose and maltose, production of indole and $\mathrm{H}_{2} \mathrm{~S}$, nitrate reduction and assimilation of $\mathrm{N}$-acetylglucosamine, adipate, arabinose, caprate, citrate, gluconate, glucose, malate, maltose, mannitol, mannose and phenylacetate. Aesculin and Tweens 20 and 80 are degraded, but casein, CMcellulose, DNA, egg yolk, gelatin, starch, L-tyrosine, urea and xylan are not. In the API ZYM gallery, alkaline phosphatase, $\beta$-glucosidase, leucine arylamidase and trypsin activities are present, but $N$-acetyl- $\beta$-glucosaminidase, acid phosphatase, $\alpha$-chymotrypsin, cystine arylamidase, esterase (C4), esterase lipase (C8), $\alpha$-fucosidase, $\alpha$ - and $\beta$-galactosidase, $\alpha$-glucosidase, $\beta$-glucuronidase, $\alpha$-mannosidase, naphthol-AS-BI-phosphohydrolase and valine arylamidase activities are absent. In the GN2 microplate (Biolog), dextrin, formic acid, pyruvic acid methyl ester, $\beta$-hydroxybutyric acid (weak), $\alpha$-D-glucose (weak), DL-lactic acid (weak) and succinic acid monomethyl ester (weak) are utilized. The remaining substrates of the Biolog GN2 system are not utilized (Supplementary Table S1). Cells are sensitive to ( $\mu \mathrm{g}$ per disc, unless indicated) amikacin (30), ampicillin 
(10), chloramphenicol (30), erythromycin (15), gentamicin (10), kanamycin (30), penicillin (10 IU), streptomycin (10) and vancomycin (30), but resistant to nalidixic acid (30), polymyxin B (300 IU) and tetracycline (30). DPG, PE, PG, SGL and PC are the major polar lipids (Supplementary Fig. S1). The predominant whole-cell fatty acids $(>5 \%)$ are $\mathrm{C}_{18: 1} \omega 7 c$, summed feature 3 (iso$\mathrm{C}_{15: 0} 2-\mathrm{OH}$ and/or $\left.\mathrm{C}_{16: 1} \omega 7 c\right), \mathrm{C}_{16: 0}, 11$-methyl $\mathrm{C}_{18: 1} \omega 7 c$, $\mathrm{C}_{16: 0} 2-\mathrm{OH}$ and $\mathrm{C}_{18: 1} \omega 9 c$. The predominant isoprenoid quinone is Q-10. The DNA G+C content of the type strain is $67.2 \mathrm{~mol} \%$.

The type strain, KYW $147^{\mathrm{T}}\left(=\mathrm{KCTC} 22735^{\mathrm{T}}=\mathrm{JCM}\right.$ $16339^{\mathrm{T}}$ ), was isolated from a seawater sample collected from the South Sea, Republic of Korea.

\section{Acknowledgements}

This research was supported by the 21C Frontier Microbial Genomics and Applications Center Program, Ministry of Education, Science \& Technology, Republic of Korea. We thank Dr S. D. Lee and Dr Z. Shao for kindly providing the type strains of $A$. marensis and $A$. marinus, respectively.

\section{References}

Barrow, G. I. \& Feltham, R. K. A. (editors) (1993). Cowan and Steel's Manual for the Identification of Medical Bacteria, 3rd edn. Cambridge: Cambridge University Press.

Bernardet, J.-F., Nakagawa, Y. \& Holmes, B. (2002). Proposed minimal standards for describing new taxa of the family Flavobacteriaceae and emended description of the family. Int J Syst Evol Microbiol 52, 1049-1070.

Chun, J. \& Goodfellow, M. (1995). A phylogenetic analysis of the genus Nocardia with 16S rRNA gene sequences. Int J Syst Bacteriol 45, 240-245.

Chun, J., Lee, J.-H., Jung, Y., Kim, M., Kim, S., Kim, B. K. \& Lim, Y. W. (2007). EzTaxon: a web-based tool for the identification of prokaryotes based on $16 \mathrm{~S}$ ribosomal RNA gene sequences. Int J Syst Evol Microbiol 57, 2259-2261.

CLSI (2003). Performance standards for antimicrobial disk susceptibility tests, 8th edn. Approved Standard M2-A8. Wayne, PA: Clinical and Laboratory Standards Institute.

Collins, M. D. (1985). Analysis of isoprenoid quinones. Methods Microbiol 18, 329-366.

Felsenstein, J. (1985). Confidence limits on phylogenies: an approach using the bootstrap. Evolution 39, 783-791.

Felsenstein, J. (1993). PHYLIP (phylogeny inference package), version 3.5c. Distributed by the author. Department of Genome Sciences, University of Washington, Seattle, USA.

Fitch, W. M. (1971). Toward defining the course of evolution: minimum change for a specific tree topology. Syst Zool 20, 406416.

Gordon, R. E. \& Mihm, J. M. (1962). Identification of Nocardia caviae (Erikson) nov. comb. Ann N Y Acad Sci 98, 628-636.

Ivanova, E. P., Bowman, J. P., Lysenko, A. M., Zhukova, N. V., Gorshkova, N. M., Kuznetsova, T. A., Kalinovskaya, N. I., Shevchenko, L. S. \& Mikhailov, V. V. (2005). Erythrobacter vulgaris sp. nov., a novel organism isolated from the marine invertebrates. Syst Appl Microbiol 28, 123-130.
Jukes, T. H. \& Cantor, C. R. (1969). Evolution of protein molecules. In Mammalian Protein Metabolism, vol. 3, pp. 21-132. Edited by H. N. Munro. New York: Academic Press.

Komagata, K. \& Suzuki, K. (1987). Lipids and cell-wall analysis in bacterial systematics. Methods Microbiol 19, 161-207.

Kovács, N. (1956). Identification of Pseudomonas pyocyanea by the oxidase reaction. Nature 178, 703.

Kwon, K. K., Woo, J.-H., Yang, S.-H., Kang, J.-H., Kang, S. G., Kim, S.-J., Sato, T. \& Kato, C. (2007). Altererythrobacter epoxidivorans gen. nov., sp. nov., an epoxide hydrolase-active, mesophilic marine bacterium isolated from cold-seep sediment, and reclassification of Erythrobacter luteolus Yoon et al. 2005 as Altererythrobacter luteolus comb. nov. Int J Syst Evol Microbiol 57, 2207-2211.

Lai, Q., Yuan, J. \& Shao, Z. (2009). Altererythrobacter marinus sp. nov., isolated from deep seawater. Int J Syst Evol Microbiol 59, 2973-2976.

Lee, K.-B., Liu, C.-T., Anzai, Y., Kim, H., Aono, T. \& Oyaizu, H. (2005). The hierarchical system of the 'Alphaproteobacteria': description of Hyphomonadaceae fam. nov., Xanthobacteraceae fam. nov. and Erythrobacteraceae fam. nov. Int J Syst Evol Microbiol 55, 19071919.

Marmur, J. \& Doty, P. (1962). Determination of the base composition of deoxyribonucleic acid from its thermal denaturation temperature. J Mol Biol 5, 109-118.

MIDI (1999). Sherlock Microbial Identification System Operating Manual, version 3.0. Newark, DE: MIDI, Inc.

Minnikin, D. E., Alshamaony, L. \& Goodfellow, M. (1975). Differentiation of Mycobacterium, Nocardia, and related taxa by thin layer chromatographic analysis of whole-cell methanolysates. J Gen Microbiol 88, 200-204.

Minnikin, D. E., O'Donnell, A. G., Goodfellow, M., Alderson, G., Athalye, M., Schaal, A. \& Parlett, J. H. (1984). An integrated procedure for the extraction of bacterial isoprenoid quinones and polar lipids. J Microbiol Methods 2, 233-241.

Ramesh Kumar, N., Nair, S., Langer, S., Busse, H.-J. \& Kämpfer, P. (2008). Altererythrobacter indicus sp. nov., isolated from wild rice (Porteresia coarctata Tateoka). Int J Syst Evol Microbiol 58, 839844.

Saitou, N. \& Nei, M. (1987). The neighbor-joining method: a new method for reconstructing phylogenetic trees. Mol Biol Evol 4, 406425.

Seo, S. H. \& Lee, S. D. (2010). Altererythrobacter marensis sp. nov., isolated from seawater. Int J Syst Evol Microbiol 60, 307-311.

Skerman, V. B. D. (1967). A Guide to the Identification of the Genera of Bacteria, 2nd edn. Baltimore: Williams \& Wilkins.

Smibert, R. M. \& Krieg, N. R. (1994). Phenotypic characterization. In Methods for General and Molecular Bacteriology, pp. 607-654. Edited by P. Gerhardt, R. G. E. Murray, W. A. Wood \& N. R. Krieg. Washington, DC: American Society for Microbiology.

Swofford, D. L. (1998). Phylogenetic analysis using parsimony (PAUP), version 4. Sunderland, MA: Sinauer Associates.

Thompson, J. D., Gibson, T. J., Plewniak, F., Jeanmougin, F. \& Higgins, D. G. (1997). The CLUSTAL_X windows interface: flexible strategies for multiple sequence alignment aided by quality analysis tools. Nucleic Acids Res 25, 4876-4882.

Yamaguchi, S. \& Yokoe, M. (2000). A novel protein-deamidating enzyme from Chryseobacterium proteolyticum sp. nov., a newly isolated bacterium from soil. Appl Environ Microbiol 66, 33373343.

Yang, S.-H., Kwon, K. K., Lee, H.-S. \& Kim, S.-J. (2006). Shewanella spongiae sp. nov., isolated from a marine sponge. Int J Syst Evol Microbiol 56, 2879-2882. 
Yoon, J.-H., Kang, K. H., Yeo, S.-H. \& Oh, T.-K. (2005). Erythrobacter luteolus sp. nov., isolated from a tidal flat of the Yellow Sea in Korea. Int J Syst Evol Microbiol 55, 1167-1170.

Yoon, J.-H., Kang, S.-J., Lee, M.-H., Oh, H. W. \& Oh, T.-K. (2006). Porphyrobacter dokdonensis sp. nov., isolated from sea water. Int J Syst Evol Microbiol 56, 1079-1083.

Yurkov, V., Stackebrandt, E., Holmes, A., Fuerst, J. A., Hugenholtz, P., Golecki, J., Gad'on, N., Gorlenko, V. M., Kompantseva, E. I. \&
Drews, G. (1994). Phylogenetic positions of novel aerobic, bacteriochlorophyll a-containing bacteria and description of Roseococcus thiosulfatophilus gen. nov., sp. nov., Erythromicrobium ramosum gen. nov., sp. nov., and Erythrobacter litoralis sp. nov. Int J Syst Bacteriol 44, 427-434.

ZoBell, C. E. (1941). Studies on marine bacteria. I. The cultural requirements of heterotrophic aerobes. J Mar Res 4, 4275 . 